\title{
Various Extension Communication Patterns that help in creating awareness of Zoonotic Diseases among Livestock Farmers: A Review
}

\author{
Insha Mir* and Ankita Rautela
}

Department of Veterinary \& Animal Husbandry Extension Education, Guru Angad Dev

Veterinary \& Animal Sciences University, Ludhiana, India

*Corresponding author

A B S T R A C T

\section{Ke ywords \\ Extension \\ communication, \\ Zoonotic diseases, \\ Livestock farmers \\ Article Info \\ Accepted: \\ 18 May 2020 \\ Available Online: \\ 10 June 2020}

\section{Introduction}

Zoonoses constitute a diverse group of viral, bacterial, ricketssial, fungal, parasitic and prion disease with a variety of animal reservoirs, including wild life, livestock, pet animals, and birds (Nkuchia et al., 2007). The transmission may occur through direct contact with the animal through vectors such as mosquitoes, fleas or ticks or through food or water contamination.

Zoonotic diseases have both direct and indirect effects on livestock health and its production (Smiths and Cutler, 2004). Indirect effects occur as a result of the risk of human disease, the economic impact on livestock producers through barriers to trade, the costs associated with control programmes, the increased cost of marketing produce to ensure if it is safe for human consumption and the loss of markets because of decreased consumer confidence (Mc Dermott and Arimi, 2002). Zoonotic diseases cause morbidity and mortality in people and is also imposing significantly losses to the livestock sector that account about $75 \%$ all emerging pathogens. Of the 1,415 known human pathogens, nearly $65-68 \%$ of the diseases are zoonotic in nature (Taylor et al., 2001). 
Many zoonotic diseases that are overlooked in endemic settings are not universally neglected. With an example of Brucellosis, well-studied and eradicated from several countries within highly developed commercial livestock sectors (Dean et al., 2012). Endemic zoonoses remain widely neglected in many low-income settings because their impact is borne largely by impoverished and marginalized communities (Molyneux et al., 2011). They disproportionately affect people who are not only at high risk of pathogen exposure but also have little access to adequate primary healthcare (ILRI, 2012). Certain occupations have a higher risk of zoonoses like occupational zoonoses that result in exposure of humans to animal diseases during work. An estimated 320,000 occupationally related deaths from infectious diseases are reported yearly worldwide (Haagsma et al., 2011). There is likelihood that majority of the animals brought for slaughter increase the risk of infection to abattoir workers (Swaiet al., 2010). Within the human activities like working with animals in their sheds, improper disposal of waste from animal sheds, skinning of infected animals, disposal of infected material from the diseased animals and poor personnel hygiene practices have been reported to be an important risk factors contributing to frequent outbreaks of zoonotic diseases in humans. Even though most of the zoonotic diseases that remain undiagnosed and result into enormous suffering and death of thousands of children and adults annually.

Since zoonotic infections remain age-long, many factors including increase contact between animals and humans continue to play a key role in their emergence and persistence. Environmental changes due to natural calamities and manmade activities, customs and traditions followed by different people in various countries, increase in human population, urbanization and increased movement of wild animals towards human habitations due to deforestation, are some of the factors responsible for spread of the zoonotic diseases. The practices which could reduce or increase the risk of zoonoses, in various livestock rearing systems and to the public as whole, will depend on awareness, perceptions, knowledge and attitude towards zoonotic behavior (Shirma et al., 2003)

In most of the under developed and developing countries farming practices, low education level, culture and eating habits, presence of reservoir population, inadequate disease control programmes and lack of knowledge about disease burden have been mostly reported to be associated with persistence of zoonotic diseases (Asbjer, 2009).

Lack of awareness with regard to zoonotic diseases is one of the most important reasons for the frequent outbreaks of zoonotic diseases in people. Awareness by various communication patterns will help to create a platform for behavior change that will help in burden of these diseases and absence of awareness could reduce the perceived threat of these disease as well as prioritization and dedication of resources to the prevention and control of disease by the government is very important. Improving awareness among the livestock farmers and proper disease diagnostic tools could be helpful in prevention of the zoonotic diseases (Agampodi et al., 2010). Public awareness and knowledge of farmers have received much attention nowadays which could be a useful tool in developing and improving existing control measures.

\section{Communication patterns with regard to dissemination awareness related to zoonotic diseases among livestock farmers}

An extension communication method depends on nature, classification and selection use of appropriate methods in implementing 
extension programmes. Communication as essential dimensions of extension work build capacity to facilitate extension teaching/ learning events in different extension situations. Understand the concept of communication and the communication process depends on the link between communication and learning which is fundamental and interlinked dimensions in creating awareness. Design and deliver effective extension messages to relevant topics will help in change of knowledge, skills and attitudes in selecting and using appropriate extension/ communication methods/techniques, devices and understand role of visual aids in extension teaching/learning situations is necessary for creating effective awareness.

Success and failure of rural development programmes often centers on the identification of communication breakthrough or communication break-down. Handled well the communication process will enable to change knowledge, awareness, behavior and attitude of millions of rural people. Communication patterns prevalent particularly regarding knowledge, awareness and risks regarding zoonotic diseases via. Interpersonal communication sources, participation in extension activities and mass media support.

So the contact with interpersonal sources by livestock farmers by and large had either frequent, occasional or rare contacts with different inter personal communication sources for information gathering as well as problem solving process and the impact of interpersonal communication sources in transfer of knowledge and awareness regarding zoonotic importance

Participation in various extension activities viz. training, meeting, demonstration, field day, Kisanmela, visit to university /Research station/ KVK will improve in knowledge gain. The awareness of livestock farmer can be done by regular training programmes organized to spread awareness regarding zoonotic diseases among livestock farmers.

Mass media which avail as the best means of information includes radio which is being available and popular amongst livestock farmers can be a good medium for transfer of awareness, T.V which is the latest and effective tool for transfer of knowledge, also use of extension literature which is found beneficial to literate livestock farmers, film shows/video shows and non-projected visual aids which avail to disseminate knowledge in a clear way can change the attitude level of farmers regarding awareness of zoonotic disease occurrence.

Extension education campaign in rural areas could be helpful in decreasing the incidence of zoonotic diseases. Limit information on posters to catch their eye with one big fact regarding zoonotic disease and pamphlets with information is something a person can take with them by a common technique to fold it into thirds with the bulk of the information inside the pamphlet which should include the most important facts about the current zoonotic in the particular area. Also information disseminate can be done by distributing print media which is a primary goals is to educate people in local languages.

\section{References}

Asbjer, E. 2009. Dog population management in Malawi and Peri. Projectreport, Department of Biomedical Sciences and Veterinary Public Health. Swedish University of Agricultural Sciences, International Journal of Recent Scientific Research, 6: 5131-5138.

Agampodi, S.B., Agampodi, T.C., Thalagala, E., Perera, S., Chandraratne, S. and 
Fernando, S. 2010. A knowledge assessment survey in post outbreak situation in Sri Lanka. International Journal of Preventive Medicine, 1(3): 158-163.

Dean A. S., Crump L., Greter, H., Hattendorf, J., Schelling, E. and Zinsstag, J. 2012. Clinical manifestations of human brucellosis: a systematic review and meta-analysis. PLOS Neglected Tropical Diseases, 6: 1929.

McDermott, J. J. and Arimi, S. M. 2002. Brucellosis in Sub-Saharan Africa: epidemiology, control and impact. Veterinary Microbiology, 90: 111-134.

Nkuchia, M. M., Ruth, L., Chris, A. B. and Henriette, V. 2007. Infectious diseases surveillance. Blackwell Publishing,2: 246-248.

Smiths, H. L. and Cutler, S. J. 2004. Contributions of Biotechnology to the control and prevention of brucellosis in Africa. African Journal of Biotechnology, 3: 631-639.

Taylor, L. H., Latham, S. M. and Woolhouse, M. E. J. 2001. Risk factors for human disease emergence philosophical transactions of the Royal Society of London series. B-Biological Sciences, 356: 983-98.

Molyneux, D., Hallaj, Z., Keusch, G. T., Mcmanus, D. P., Ngowi, H.,
Cleaveland, S. and Ramos-Jimenez. 2011. Zoonoses and marginalised infectious diseases of poverty: where do westand. Parasites and Vectors, 4: 106.

International Livestock Research Institute (ILRI). 2012. Mapping of poverty and likely zoonoses hotspots. Zoonoses Project: Report to Department for International Development in Nairobi, Kenya. International Livestock Research Institute, 119.

Haagsma, J.A., Tariq, L., Heederik, D.J. and Havelaar, A. H. 2011. Infectious disease risks associated with occupational exposure: A systematic review of the literature. Occupational Environmental Medicine, 6(3):111-115.

Swai, E. S., Schoonman, L. and Daborn, C. J. 2010. Knowledge and attitude towards zoonoses among animal health workers and livestock keepers in Arusha and Tanga, Tanzania. Journal of Health Research, 12(4): 205-209.

Shirima, G.M., Fitzpatrick, J., Cleaveland, S., Kambarage, D.M., Kazwala, R.R., Kunda, J. and French, N. P. 2003. Participatory Survey on Zoonoses affecting Livestock Keeping communities in Tanzania. Journal of Animal and Veterinary Advances, 4: 253-258.

\section{How to cite this article:}

Insha Mir and Ankita Rautela. 2020. Various Extension Communication Patterns that help in creating awareness of Zoonotic Diseases among Livestock Farmers: A Review. Int.J.Curr.Microbiol.App.Sci. 9(06): 2287-2290. doi: https://doi.org/10.20546/ijcmas.2020.906.280 